\title{
Interactive Learning Media Development in Capital Market Subject Using Macromedia Flash Integrated Home Online Trading System (HOTS)
}

\author{
Chandra Situmeang \\ Education Technology Study Program \\ Universitas Negeri Medan \\ Medan, Indonesia \\ chandra@unimed.ac.id \\ Efendi Napitupulu \\ Education Technology Study Program \\ Universitas Negeri Medan \\ Medan, Indonesia \\ napitupuluefendi@gmail.com \\ Sahat Siagian \\ Education Technology Study Program \\ Universitas Negeri Medan \\ Medan, Indonesia
}

\begin{abstract}
This research is conducted because there are problems of student difficulty learning outcome in capital market subject in accounting department of economics faculty, Universitas Negeri Medan. Learning outcome is related to knowledge and technical skills in executing stock trading transactions. To overcome this will be built interactive learning media which integrated macromedia flash with stock trading trading software Home Online Trading System (HOTS) which connected directly to Indonesia Stock Exchange. The resulting interactive learning media is assessed and responded by various parties. Assessment conducted by capital market material experts reached the level of $91.17 \%$ percentage, this means that the substance of interactive learning media produced can be categorized as very feasible. Assessment made by software experts reached the level of $83.33 \%$ so that it can be interpreted that the resulting software media is very feasible from the implementation as a computer application. Assessments made by the learning design expert reaches the presentation level of $86.35 \%$, so it can be said if analyzed from the aspects of instructional design, then the interactive learning media produced is very feasible to use. The result of students response reached $89.99 \%$ percentage level so it can be concluded that the learning media is very feasible to be used. Based on the above, the learning media generated through research conducted and manufactured with tools macromedia flash integrated with HOTS is very feasible to be used as learning instrument, especially for the achievement of learning related to knowledge and technical trade in the stock market.
\end{abstract}

Keywords - interactive learning media, capital market subject.

\section{INTRODUCTION}

The activities of modern society can not be separated from the business matter because business activities become one of the important parts that determine the level of welfare of a society. In the development of the business, one of the most important aspects is looking for funding for business development. One of the most effective sources of funding comes from the capital market. The importance of capital market make this area become a mandatory subject on business courses. This course has a very important role because it provides a broad understanding of business activities comprehensively. The capital market links the internal management of the firm with the business enviroment that lies outside the company.

Capital market course is one of the subjects that desperately need experience of learning directly. The material acquired in the learning process can not be fully mastered without performing a practice, at least in a simulated activity. Students should be encouraged to feel the activities of the capital market, especially in buying and selling shares using real conditions both in terms of tools, data, time, and so forth. In the rapid development of information technology such as today, this can be achieved relatively easily. Lecturers can use existing facilities in Unimed and industry relation so that students can get that

The significance of capital market learning makes colleges including Universitas Negeri Medan (Unimed) should 
implement capital market learning efficiently and effectively. Based on the data on the 2015/2016 academic year, 90 students received 17 students (18.9\%), B as many as 42 people $(46.7 \%)$, 24 people $(26.7 \%)$, and $\mathrm{E}$ as many as 7 people $(7.8 \%)$. Effectiveness measures of capital market learning are more fair using standard test questions used in certification in the capital market. Tests conducted with the question of professional certification in the capital market followed by 40 people only produce tilapia on average of 62 while the passing score is 85 . The number of students who passed from the test was only five people from 40 test takers. Based on the value of capital market courses and tests using standardized problems shows that the effectiveness of capital market learning in FE Unimed accounting majors is still not optimal.

Such ineffectiveness is most likely due to a discrepancy between the method of learning and the characteristics of the students following the course. Capital market learning that relies heavily on the use of information technology along with the development of information technology is not in accordance with conventional learning. The mismatch of these learning methods allegedly made the students' learning spirit not optimal. On the other hand, it was found that variations in students' abilities were widening. This means that among students who have good and bad learning skills to be wider. This certainly makes it difficult for lecturers to ensure the achievement of a uniform learning achievement of all students who attend the lectures. This can be minimized by providing a method of learning where students can determine the speed of learning and sequencing. Alavi \& Leidner (2001) stated that interactive learning can help learners to respond actively that determines the speed and sequence of learning.

Aditya \& Nurhayati (2016) conducting research in Electrical Engineering State University of Surabaya that the use of interactive learning media that combines some software resulted in the conclusion that the students give a good enough response which means the learning media produced strongly supports the learning process. More specifically the research undertaken by Suhendro \& Chomsatu (2014) which examines online capital market simulation-based learning models in private universities in the Surakarta region. The results showed that students feel the ease and great benefits in using the BEI virtual trade (> 50\%) so that the learning capital market more interesting. Other studies supporting this conclusion were also made by Khan \& Kharat (2016); Pelupessy \& Agustin (2014); and Saputro \& Ismayati (2013).

Based on the above explanation, especially the previous research results provide the direction that the use of interactive learning media based on information and communication technology into a solution to solve the problem of ineffectiveness of the learning process. Online learning media based online becomes more effective because the student lifestyle are very close to the internet. Ownership of gadgets such as laptops, smartphones, and other online gadgets is driving a culture which highly dependent on information technology. The learning process have to adjust it and improve its effectiveness by trying to blend with the change of trend.

Particularly in capital market courses, the utilization of information technology is very crucial. At this time worldwide stock trading is connected in a global network through the use of the internet. If the capital market learning process can be integrated with real business activity, then it will not only encourage the quality improvement of the study substance for each topic, but it can increase the students' learning spirit. This can happen because students feel a very interesting learning experience because it uses real time and real data.

One of the software that helps in developing interactive learning media is Macromedia Flash. Macromedia Flash is a software that provides facilities to support the needs of Full Service Authoring Tolls that can be used to develop digital content of lecture material and test materials in the form of dynamic, easy and quality multimedia such as text, graphics, sound, moving pictures and video. Macromedia flash as an interactive learner media application will be more useful if integrated with online application media supporting the learning process. In the capital market review one of the most useful applications is the online trading application. There are several online stock trading applications both simulated and real applications. One of the fairly easy to download is Home Online Trading System (HOTS) provided by PT Mirai Securities. This application can be integrated with interactive learning media as a tool to support practice special skills related to stock trading. The combination of these two things is expected to minimize the previously disclosed problem of students who are not enthusiastic and can not implement personal learning.

\section{LITERATUR REVIEW}

Gagne \& Briggs (1974) states "learning achievements can be grouped into 5 (five) categories: (1) intellectual skills, (2) verbal information, (3) cognitive strategies, (4) motor skills, and (5). This opinion is interpreted: First, the intellectual skills (intellectual skills). Learning intellectual skills means learning how to do things intellectually. There are six types of intellectual skills: (1) discriminations, ie the ability to make different responses to different stimuli; (2) concrete concepts, namely the ability to identify the characteristics or attributes of an object; (3) defined concepts, ie the ability to give meaning to a group of objects, events, or relationships; (4) rules, namely the ability to respond to relationships between objects and events; (5) high level rules, that is, the ability to respond to relationships between objects and events more complexly; (6) solve the problem, namely the ability to solve problems that usually involve high-level rules. Second, cognitive strategies (cognitive strategies).

Each process produces an outcome including by learning. Learn to produce something that needs to be measured for its effectiveness. Learning outcomes are the value of student learning through activities and measurements (Dimyati, 2002) while Sudjana (2002) sees from a different perspective by saying that learning outcomes are the abilities students have after receiving a learning experience. In terms of learners, the learning result is the end of the base and the peak of the learning process while for the lecturer or teacher can be interpreted as an achievement of teaching objectives. Learning outcomes are differentiated into the impact of teaching and impact accompaniment. The impact of teaching is a measurable outcome, as embodied in the report card and the impact of 
accompaniment is the application of knowledge and skills in another field, a learning transfer (Dimyati, 2002).

According to Ahmad (2007) learning media is a tool used as an intermediary to convey messages and can stimulate the mind, feelings, and progress of the audience (learners) so as to encourage the learning process. Miarso (2007) argues that well-designed media can in some instances stimulate the emergence of a kind of internal dialogue in learners that learns that there is communication between learners with the media or indirectly between learners with a message source or educator. Media managed to bring the message to learn if then there is a change in the quality of the students. The presence of the media will make educators can increase the interest of learners in the learning process and learners can more quickly understand and understand the material presented educators.

Dzamarah \& Zain (2006) suggests that instructional media is anything that can be used to channel messages from the sender to the recipient so as to stimulate the students' thoughts, feelings, concerns and interests in such a way that the learning process occurs. The medium of learning in the broad sense is that the media not only include complex electronic communication media, but also includes simple tools, such as slides, photographs, diagrams, and artificial lecture charts, real objects as well as out-of-school visits (Hamalik , 2005). Gerlach \& Ely (1971) says that educational media when understood in broad outline is human, material, or events that build conditions that enable students to acquire knowledge, skills or attitudes. Teachers / lecturers, books, text and school environment are the media.

One of the methods and learning media is electronic learning or often written e-learning. E-learning, defined as a virtual learning environment in which learners interact with learning materials, peers and / or instructors is mediated through information technology. E-learning is currently the fastest-growing learning method (Alavi \& Leidner, 2001). The 2007 and 2009 American Society for Training and Development (ASTD) industry statement reported that the United States organization spent \$ 134.07 billion in employee training and development, with more than $36 \%$ training conducted using e-learning methods (ASTD, 2007, ASTD , 2009). American private investment in learning technology companies that provide e-learning learning devices reached more than $\$ 1$ billion in 2008, the highest value in the period 1998-2008 (ASTD, 2009).

E-learning has advantages in aspects of scale, geographic coverage, time flexibility, and speed of information delivery and updating (DeRouin et al., 2005; Weaver, 2002). However, this advantage can be achieved if done under certain conditions: the e-learning strategy must be in accordance with the overall institutional strategy. The e-learning system should also be implemented appropriately where the administrator must ensure that the resources and expertise required for the elearning program must be well prepared and motivated (Bostrom, 2003; DeRouin et al., 2004; Romiszowski, 2004; Salas et al ., 2002; Weaver, 2002).

\section{CONCEPTUAL FRAMEWORK}

Based on the explanation in the introduction, theoritical review, and previous research to obtain good learning result, it needs an effective, efficient and attractive learning media. To achieve that purpose, then media designer need to develop appropriate learning media. Learning media which developed should be based on identification of needs. The design adjustto the needs will make students and lecturers can use the media optimally. A series of trials and revisions should be done as a procedure a decent learning software.

The expected outcome in this activity is to develop a viable interactive learning media and according to the learning needs of capital market courses. Interactive learning media will be packed in multimedia concept using Macromedia Flash Professional 8 software integrated with Home Online Trading System (HOT) 3.0. The use of learning media is expected to make students more able to master the substance of the material because the use of real data and expected use of interesting media will increase student motivation to study the capital market.

The creation of media packaged in interactive media with Macromedia Flash Professional 8 integrated Home Online Trading System (HOTS) 3.0, is expected to stimulate users to explore the entire contents of learning as it can display text, graphics, data, images, animated learning that are interesting simultaneously. The use of interactive learning media is expected to improve students' ability both in terms of cognitive abilities but and psychomotor ability of students because they are accustomed to using standard applications. Based on the above, students are expected to be able to understand and apply the learning materials in accordance with the learning objectives.

Learning media is a means of communication between lecturers and students. Interactive media is expected to be a more effective means of communication than other conventionally used media. The use of the media is expected to encourage the effectiveness of achieving competency standards through ease of understanding the substance and attractiveness of students. Mechanisms and tools available in the media both in an attractive and engaging manner that engage students through hands-on experience will enable students to enjoy exciting and non-boring learning processes.

The development of interactive learning media using Macromedia Flash Professional 8 integrated Home Online Trading System (HOTS) 3.0 enables the creation of interactive learning media that is more effective in learning. The effectiveness criteria in question is a measure related to the level of success of the learning process. Effective learning is a learning that allows students to learn easily, fun, enjoy learning experiences, and can achieve the desired learning objectives. In learning effectiveness is not solely seen from the level of success of learners in mastering the concept shown by the value of learning outcomes but also from the participants' responses in learning.

In order to achieve the expected effectiveness, a lecturer should complete the learning with appropriate media with material content which includes images, audio, simulation or 
direct practice with real data, etc. Interactive learning media is expected to help improve understanding through presentation of presentations by attracting, providing facilities for real learning experiences, providing feedback mechanisms to students so as to measure students' learning abilities after learning. The use of media in the delivery process is expected to improve the effectiveness of learning to improve learning outcomes. So this study suspects with the development and use of instructional media packaged in the form of interactive media Macromedia Flash Professional 8 integrated Home Online Trading System (HOTS) 3.0, then the learning outcomes will be more effective than the previous media usage is the power point media.

\section{METhODOLOGY}

In making the interactive learning media in this research used Borg and Gal development model (1983) which integrated with development model of Dick, Carey L, and Carey J, O (2005). The development procedure taken to produce the product of interactive learning media of capital market is divided into 6 stages: (1) first stage of preliminary research, (2) second stage of software design, (3) third stage of material collection, (4) fourth stage create and produce interactive learning media, and (5) the fifth stage of review or field test in the framework of formative evaluation and ongoing product revision, (6) Product effectiveness test.

This research is carried out in Accounting Department of Faculty of Economics, State University of Medan in student of capital market course even semester of academic year 20162017. Implementation in May 2016. Treatment (experiment) conducted during 2 meetings with a time allocation of $2 \times 150$ minutes per meeting. The learning process is carried out in the classroom.

The instrument used is the test of learning results in the form of multiple choice which amounts to 25 questions, each of which consists of 5 options namely a, b, c, d, and e. Scoring technique for this objective is based on the correct answer, meaning that for students who answer correctly on each item will be given a score of 1 (one) and for students who answered wrong will be given a score of zero (zero). So the minimum score is 0. Data analysis in this study using quantitative analysis techniques.

\section{DISCUSSION}

Based on the stages that have been planned by using Borg and Gal model (1983) with Dick, Carey L, and Carey J, O (2005) it has been produced interactive media with Macromedia Flash application by integrating it with Home Online Trading System (HOTS). The resulting media can be used relatively personally by the students to adjust to the personal learning characteristic. The media also can directly connect to the stock exchange to obtain the latest trade simulation data. Furthermore the media has been given to media experts, substance experts, design learning experts to obtain an assessment.

The resulting interactive learning media is assessed and responded by various parties. Assessment conducted by capital market material experts reached the level of $91.17 \%$ percentage, this means that the substance of interactive learning media produced can be categorized as very feasible. Assessment made by software experts reached the level of $83.33 \%$ so that it can be interpreted that the resulting software media is very feasible from the implementation as a computer application. Assessments made by the learning design expert reaches the presentation level of $86.35 \%$, so it can be said if analyzed from the aspects of instructional design, then the interactive learning media produced is very feasible to use. The result of students response reached $89.99 \%$ percentage level so it can be concluded that the learning media is very feasible to be used.

\section{CONCLUSION}

Based on the assessment from various parties who have the competence to assess the quality of learning media that has been produced can be coblude that the learning media generated through research conducted and manufactured with tools macromedia flash integrated with HOTS is very feasible to be used as learning instrument, especially for the achievement of learning related to knowledge and technical trade in the stock market. This media will be used as a tools to help the learning process of capital market so it is expected to improve learning achievement of capital market subject.

\section{References}

[1] Aditya, M. R., \& Nurhayati. (2016). Pengembangan Media Pembelajaran Menggunakan Lectora dan Software High Frequency Structure Simulator (HFSS) untuk Menunjang Materi Antenna pada Mata Kuliah Antenna dan Propagasi di Jurusan Teknik Elektro Universitas Negeri Surabaya. Jurnal Pendidikan Teknik Elektro, 5(1), 317-324.

[2] Ahmad, Sabri. (2007). Strategi Belajar Mengajar Micro Teaching. Ciputat : Quantum. Teaching

[3] Alavi, M., and Leidner, D.E. (2001). Research commentary: Technology-mediated leaming-A call for greater depth and breadth of research. Information Systems Research, 12(1), 1-10.

[4] ASTD. (2007). State of the Industry Report. The American Society for Training and Development.

[5] ASTD. (2009). State of the Industry Report. The American Society for Training and Development.

[6] Bostrom, R.P. (2003). E-leaming: Facilitating Learning through Technology. the Ninth Americas Conference on Information Systems, 3159-3164.

[7] DeRouin, R.E., Fritzsche, B.A., and Salas, E. (2005). E-Leaming in Organizations. Journal of Management, 31(6), 920-940.

[8] Dimyati, M. (2002). Belajar dan Pembelajaran. Jakarta: PT. Rineka Cipta.

[9] Djamarah, \& Zain. (2006). Strategi belajar mengajar. Jakarta: Rineka Cipta.

[10] Gagne R. M. \& Briggs L. J. (1974). Principles of instructional design. New York: Holt, Rinehart \& Winston.

[11] Gerlach, \& Ely. (1971). Teaching \& Media: A Systematic Approach. Second Edition. Boston, MA: Allyn and Bacon.

[12] Hamalik, Oemar. (2005). Kurikulum dan Pembelajaran. Jakarta: Bumi Aksara

[13] Khan, M. R., \& Kharat, R. B. (2016). Design \& Analysis of E-Learning System for MCA Programme. International Journal of Information, Business and Management, 8(3), 96-111.

[14] Pelupessy, E. T., \& T. Agustin, H. P. (2014). Pengembangan Media Pembelajaran Berbasis E-Learning pada Mata Kuliah Fisika 1 untuk 
[15] Meningkatkan Efektifitas Belajar Mahasiswa. Jurnal Pendidikan Teknik Elektro, 3(2), 193-198.

[16] Romiszowski, A.J. (2004). How's the e-learning baby? Factors leading to success or failure of an educational technology innovation. Educational Technology, 44(1), 5-27.

[17] Romiszowski. (1988). The Selection and Use of Instructional Media. United States: Nichols Publishing.

[18] Salas, E., Kosarzycki, M.P., Burke, C.S., Fiore, S.M., and Stone, D.L. (2002). Emerging themes in distance learning research and practice: some food for thought. International journal of management reviews, $4(2), 139-153$

[19] Saputro, F. D., \& Ismayati E. (2013). Pengembangan Media Pembelajaran Menggunakan Model Computer Based Instruction (CBI) pada Materi Fisika Gelombang. Jurnal Pendidikan Teknik Elektro, 2(1), 169-175.

[20] Sudjana, N. (2002). Dasar-dasar Belajar Mengajar. Bandung: Tarsito.

[21] Suhendro \& Chomsatu, Y. (2014). Model Pembelajaran Pasar Modal Berbasis Simulasi Perdagangan Daring Melalui Perdagangan Maya BEI Jurnal Akuntansi Multiparadigma JAMAL Vol 5, Nomor 2, hal 170-344. 